Egyptian Journal of Aquatic Biology \& Fisheries

Zoology Department, Faculty of Science,

Ain Shams University, Cairo, Egypt.

ISSN $1110-6131$

Vol. 23(2): 291 - 302 (2019)

www.ejabf.journals.ekb.eg

\title{
Comparative study on antimicrobial activity of commercial and extracted chitin and chitosan from Marsupenaeus japonicus shells
}

\author{
Eman H. Zaghloul and Hassan H.A. Ibrahim* \\ Marine Microbiology Lab., Marine Environment Division, National Institute of \\ Oceanography and Fisheries \\ *Corresponding author: drhassan1973@yahoo.com
}

\section{ARTICLE INFO \\ Article History: \\ Received: Feb. 13, 2019 \\ Accepted: April 30, 2019 \\ Online: May 2019}

Keywords:

Chitin

Chitosan

Marsupenaeus japonicas FTIR

Antimicrobial activity
ABSTRACT

Chitin was extracted from the skeleton of Marsupenaeus japonicus shrimp shell waste with a yield of $27.7 \%$ of the net weight through three steps namely; deproteinization, decolourization and demineralization. After deacetylation process of extracted chitin, chitosan was produced and represented $55.1 \%$ of the extracted chitin. Scanning electron microscope and Fourier Transform Infrared spectroscopy (FTIR) analyses were conducted to characterize the obtained chitin and chitosan. The FTIR analysis revealed different absorption bands within $4000-400 \mathrm{~cm}^{-1}$ range; by comparison these bands were found to be similar to those of commercial chitin and chitosan and confirmed partial deacetylation in the produced chitosan. Moreover, the antimicrobial activity of commercial and extracted chitin and chitosan were examined against different pathogenic Gram positive, Gram negative bacteria and fungi using agar well diffusion test. Results showed that there was no significant difference $\mathrm{p}<0.05$ in the antimicrobial activity of the extracted compounds and commercial ones against test pathogens as the extracted compounds recorded inhibition zones ranged from 12 to $23 \mathrm{~mm}$ in diameter while the commercial compounds recorded inhibition zones of diameters ranged from 12 to 22 mm only; with Staphylococcus aureus ATCC 25923 being the most affected microbe with inhibition zone of $23 \mathrm{~mm}$ produced by extracted chitin, while the lowest zone of inhibition was recorded against Enterococcus faecalis ATCC 29212 with only $12 \mathrm{~mm}$ by commercial and extracted chitosan.

\section{INTRODUCTION}

Crustacean processing produces about $40 \%$ of shell waste (Gildberg and Stenberg, 2001). The global annual production of shell waste is estimated to be 1.44 million metric tons dry weight (Rodde et al., 2008; Kean and Thanou, 2011). Since biodegradation of this waste is very slow, accumulation of large quantities has become a major concern in the seafood processing industry. Therefore, the use of this waste to produce renewable products such as biopolymers is a dual-purpose opportunity. The Crustacean shells consist mainly of chitin, proteins, lipids, pigments and trace elements. Chitin, calcium carbonate and proteins account for about $90 \%$ of the dry weight of the shell (Rodde et al., 2008; Benhabiles et al., 2012). 
The extraction of chitin from the shells is achieved in three steps: 1) deproteination, 2) removal of lipids and pigments and 3) demineralisation. The chitin extraction steps and its subsequent conversion to chitosan can be carried out chemically or by using biological methods, such as microbial fermentation and enzymatic reactions (Acharya et al., 2005; Rinaudo, 2006).

Chitosan is a technologically important polysaccharide biopolymer. Chemically, it is a high molecular weight linear polycationic heteropolysaccharide consisting of two monosaccharides, N-acetyl-D-glucosamine and D-glucosamine, linked together by $\beta-(1 \rightarrow 4)$ glycosidic bonds. Chitosan is primarily produced from chitin by exhaustive alkaline deacetylation, this process involves boiling chitin in concentrated alkali for several hours. Since this $\mathrm{N}$-deacetylation is almost never complete, chitosan is considered as a partially N-deacetylated derivative of chitin (Fouad, 2008).

Moreover, early research described the antimicrobial potential of chitin, chitosan, and their derivatives (Chen et al., 1998; Shahidi et al., 1999). Numerous bacteria and fungi are highly pathogenic causing various infectious diseases (Chistiakov et al., 2007). The increasing economic and social concern to decrease the use of antibiotics and other therapeutic chemicals has encouraged more environmentally friendly approaches to control diseases (Torrecillas et al., 2007). Interestingly, chitin and chitosan have been investigated as an antimicrobial agents against a wide range of target organisms like algae, bacteria, yeasts and fungi in experiments involving in vivo and in vitro interactions in different forms (solutions, films and composites) (Goy et al., 2009).

Generally, in these studies the chitosan is considered to be a bactericidal (kills the live bacteria) or bacteriostatic (hinders the growth of bacteria but does not imply whether or not bacteria are killed), often with no distinction between activities. Recent data in literature has the tendency to characterize chitosan as bacteriostatic rather than bactericidal (Coma et al., 2002; Toan et al., 2013) and it has been shown to inhibit growth of several fungi and bacteria, especially pathogens (Islam et al., 2011). Although, various theories have been proposed to explain the mechanism of the antibacterial activity of chitosan, intracellular leakage hypothesis is widely accepted (El-Badawy et al., 2003; Kong et al., 2010). Positive charge of chitosan binds to the negative charge on the surface of the bacterial cell causing altered membrane permeability which leads to leakage of intracellular constituents causing cell death. Therefore, the antibacterial activity of chitosan is suggested to be limited to acidic condition as the positive charge of chitosan amino group is lost at neutral $\mathrm{pH}$ (Qi et al., 2004; Liu et al., 2004).

Therefore, the objective of this study was to extract and characterize chitin and chitosan from shrimp (Marsupenaeus japonicus) shells and to test the possibility of using them as safe and eco-friendly antimicrobial agents. Moreover, the current study aimed to compare this activity with commercial chitin and chitosan.

\section{MATERIALS AND METHODS}

All chemicals used in this study were of analytical grade and purchased from local suppliers. Shrimp shells were obtained from fish market, Alexandria. 


\section{Pretreatment of shrimp shells for chitin extraction}

Shrimp shell waste were collected and washed three times thoroughly using tap water to remove the salt on its surface, followed by washing with distilled water then spreading on blotting paper to remove excess water. They were dried by hot air oven at $70^{\circ} \mathrm{C}$ overnight. All dried shrimp shells were milled using a laboratory hammer mill in order to obtain a particle size less than $0.5 \mathrm{~mm}$.

\section{Determination of $M$. japonicas shell chemical composition}

The chemical composition of $M$. japonicas shrimp shells was determined by Plant Biochemistry Department, Agricultural Research Center, Giza, Egypt. Moisture content was considered as the losses in mass from a sample $(1 \mathrm{~g})$ after drying at $100^{\circ} \mathrm{C} \pm 2{ }^{\circ} \mathrm{C}$. The residual mass in this sample was heated at $600^{\circ} \mathrm{C} \pm 10^{\circ} \mathrm{C}$ to determine the ash content. The organic matter was calculated through the difference between $100 \%$ and the sum of moisture content and ash values.

Nitrogen was measured by Kjeldahl method using the distiller-digester (Yokoyama and Guimarães, 1975). Once the nitrogen content has been determined it is converted to a protein content using the appropriate conversion factor.

Protein $\%=\mathrm{F} \times \mathrm{N} \%$ where $\mathrm{F}$ (Conversion factor) $=6.25$ and $\mathrm{N} \%$ is the nitrogen percent.

For lipid contents, $2 \mathrm{~g}$ of sample was extracted with ethyl ether in Soxhlet extractor for $5 \mathrm{~h}$. The solvent was evaporated and the residual mass on the balloon was considered lipids (Pádua et al., 2004). Subtraction of the sum of moisture content, protein, lipids, chitin and ash values from 100 was the carbohydrate contents in percentage (Pádua et al., 2004).

\section{Chitin extraction}

In order to obtain purified chitin, it must be separated from the proteins, minerals and other components. This separation was achieved in three steps according to Mohammed et al. (2013) with slight modifications as follows:

1- Deproteinization by $5 \% \mathrm{NaOH}(\mathrm{w} / \mathrm{v} 1: 8)$ at $60^{\circ} \mathrm{C}$ for $2 \mathrm{~h}$ then the sample was washed with distilled water and dried at $60^{\circ} \mathrm{C}$ until constant weight.

2- Decolourization by treatment with acetone (w/v 1:10) for $24 \mathrm{~h}$ at room temperature followed by bleaching with $0.315 \% \mathrm{NaOCl}(\mathrm{w} / \mathrm{v} 1: 10)$ for 5 min then the sample was washed with distilled water and dried at $60^{\circ} \mathrm{C}$ until constant weight.

3- Demineralization of the produced material by 0.5 or $1 \% \mathrm{HCl}$ solution (w/v 1:4, $1: 10)$ for $24 \mathrm{~h}$ at $25^{\circ} \mathrm{C}$ to dissolve calcium carbonate.

The sample was washed with distilled water to remove $\mathrm{CaCl}_{2}$ and other water soluble impurities. At the end, the extracted chitin was in the form of light brown powder. The shrimp shell chitin contents were calculated as the weight difference of the obtained chitin and the raw dried shrimp shell waste (Mohammed et al., 2013).

\section{Deacetylation of chitin for chitosan production}

Chemical deacetylation was achieved by treatment of extracted chitin with $50 \% \mathrm{NaOH}$ solution (w/v 1:5) at elevated temperature and then boiled at $100^{\circ} \mathrm{C}$ for 2 $\mathrm{h}$ on a hot plate. After the reaction the material produced was washed several times with distilled water until near to neutral $\mathrm{pH}$ and dried at $60^{\circ} \mathrm{C}$ in a vacuum oven until constant weight. The chitosan obtained had a white creamy form (Muzzarelli and Rochetti, 1985, Mohammed et al., 2013).

\section{Characterization of the extracted chitin and chitosan:}

\section{Fourier Transform Infrared Spectroscopy (FTIR) analysis}

Chitin and chitosan samples were ground to a very fine powder with $\mathrm{KBr}$ and dried thoroughly. The dried mixture was pressed under vacuum in a mould to form a 
$\mathrm{KBr}$ disc containing the sample. The FTIR spectra were recorded using a Perkin Elmer FTIR Spectrometer according to Kumirska et al. (2010) over the frequency range of $4000-400 \mathrm{~cm}^{-1}$.

\section{Scanning electron microscopy}

The extracted chitin and chitosan samples were examined and photographed using SEM (JSM-5300 - JEOL, Japan), available through Faculty of Science, Alexandria University.

\section{Antimicrobial activity assay}

Five microbial pathogens namely; Enterococcus faecalis ATCC 29212, Staphylococcus aureus ATCC 25923, Bacillus subtilis ATCC 6633, Escherichia coli ATCC 8739 and Candida albicans ATCC 10231 were grown over night in nutrient broth at $37^{\circ} \mathrm{C}$.

Gels were prepared by dissolving one gram of chitin or chitosan in $99 \mathrm{ml}$ of $1 \%$ glacial acetic acid $(\mathrm{pH} 4)$ to produce gels with $10 \mathrm{mg} / \mathrm{ml}$ final concentration. The gels were homogenized for $6 \mathrm{~h}$ at $60^{\circ} \mathrm{C}$ under moderate stirring conditions. A commercial chitin (Loba chemie, India- Mwt: 400,000) and chitosan (Acros Organics, USA- Mwt: 100,000-300,000) were dissolved under the same conditions for comparison. In addition a $1 \%$ glacial acetic acid was serving as a control. After homogenization all preparations $\mathrm{pH}$ were adjusted to $5.6 \pm 0.2$ (slightly acidic). The well diffusion method (Rayn et al., 1996) was used to evaluate the antimicrobial activity of all preparations against the indicated pathogens, separately. Briefly, each pathogen $(1 \% \mathrm{v} / \mathrm{v})$ was inoculated in nutrient agar plates then, wells $(8 \mathrm{~mm}$ in diameter) were punched onto the surface using a sterile borer. A $150 \mu \mathrm{L}$ of each preparation were added separately to wells. Plates were stored at $4^{\circ} \mathrm{C}$ for $30 \mathrm{~min}$ to allow diffusion. All plates were prepared in triplicates and they were incubated at $37^{\circ} \mathrm{C}$ for $24 \mathrm{~h}$ before examination. A clear inhibition zone at least $10 \mathrm{~mm}$ in diameter was recorded as positive.

\section{RESULTS AND DISCUSSION}

In this article chitin was extracted according to the method mentioned before from the skeleton of $M$. japonicus shrimp with $27.7 \%$ of net weight. This result with the other chemical compositions of the shrimp shells are illustrated in Table 1.

\begin{tabular}{lc} 
Table 1: Chemical composition of $M$. japonicas shrimp shells \\
\hline \multicolumn{1}{c}{ Constituent } & \% to dry wt. \\
\hline Moisture content & 21.1 \\
Ash content & 5.2 \\
Organic matter: & 73.7 \\
Chitin & 27.2 \\
Crude protein & 16.3 \\
Carbohydrate & 19.3 \\
Lipids & 10.9 \\
\hline
\end{tabular}

Abdou et al. (2007) extracted chitin from six different local sources in Egypt. They converted the obtained chitin into the more useful soluble chitosan by steeping into solutions of $\mathrm{NaOH}$ of various concentrations for extended periods of time, then the alkali chitin was heated in an autoclave which dramatically reduced the time of deacetylation. So, in this study, we exposed the chitinous wastes collected from shrimp to $\mathrm{NaOH}$, followed by $\mathrm{HCl}$ to obtain treated chitin shells (Ibrahim et al., 2015). 
The chitosan yield was $55.1 \%$ of the produced chitin extracted from the total exoskeleton taken. By comparison, Puvvada et al. (2012) collected the crude chitin from exoskeleton of Triops longicaudatus and Triops cancriformis specimens which are then processed to obtain chitosan. The chitosan yield was found to be $35.49 \%$ and it was analyzed for its physiochemical parameters. On the other hand, Paul et al. (2014) focused on the purification of chitosan from chitin isolated from Fenneropenaeus indicus for pharmaceutical industry. However, Paul et al. (2014) found that the chitosan yield was $57.69 \%$.

As shown in Fig. 1, the extracted chitin and chitosan from the M. japonicus shrimp shells, chitin can be seen as a light brownish powder, while the produced chitosan obtained by chitin deacetylation exhibited a creamy color. On the other hand, Fig. 2 indicates scanning electron microscopy image of the extracted chitin and chitosan.
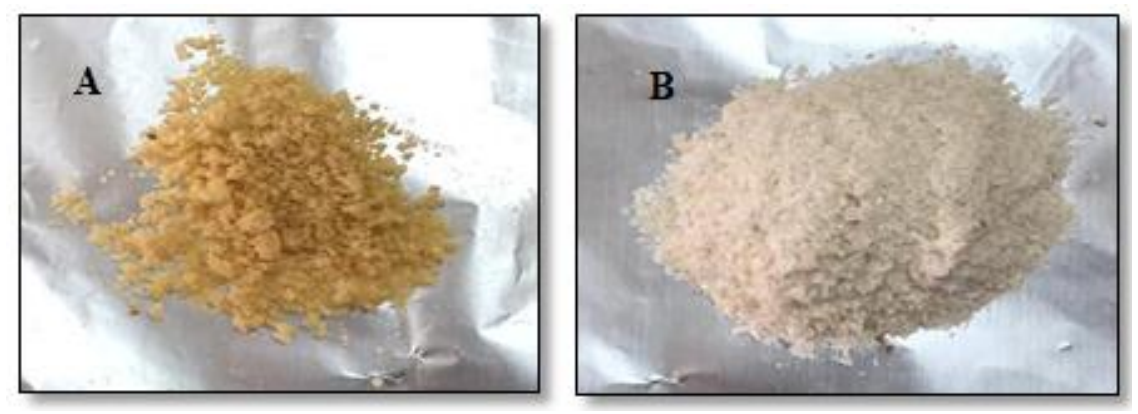

Fig. 1: Crude chitin (A) and chitosan (B) extracted from M. japonicus shells.
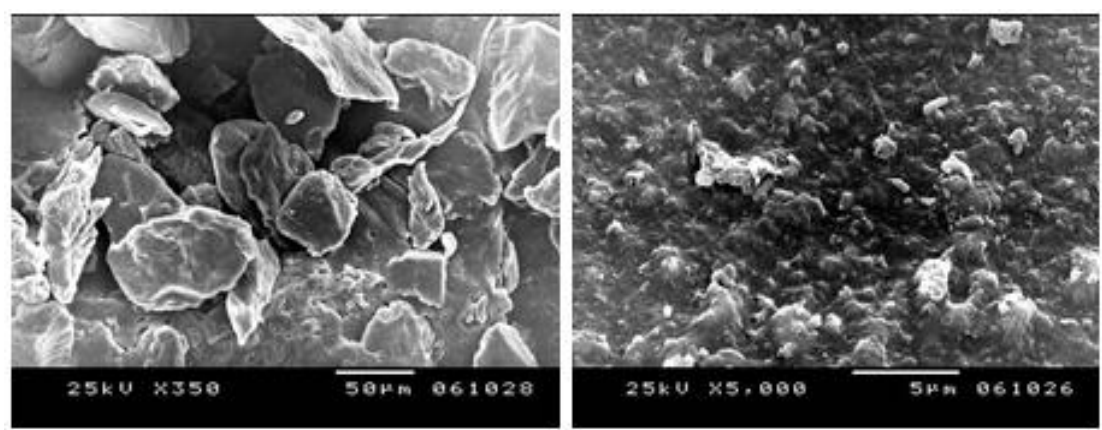

Fig. 2: Scanning electron microscopy image of Chitin (left) and Chitosan (right) extracted from $M$. japonicus shells.

Data in Fig. 3 and Table 2 demonstrates the FTIR spectrum of extracted chitin in the range of 4000-400 $\mathrm{cm}^{-1}$. Bands between 1200 and $1100 \mathrm{~cm}^{-1}$ are assigned to $\mathrm{C}$ $\mathrm{C}$ and C-O modes including a shoulder due to C-O.C of the glycosidic linkage (1153 $\mathrm{cm}^{-1}$ ). The spectra for the $\mathrm{OH}$ bending modes and sugar $\mathrm{OH}$ stretching were observed at $3256 \mathrm{~cm}^{-1}$. However, the absorption bands of produced chitin were identical to those of standard chitin.

These findings were in the agreement of results obtained by Rinaudo, (2006) and Kumirska et al. (2010). They confirmed that Amide I band, which is responsible for the splitting of wave numbers between 1600 to $1500 \mathrm{~cm}^{-1}$, corresponds to the inter-sheet hydrogen bonding due to the hydroxymethyl group that can be associated to the band peak at $1630 \mathrm{~cm}^{-1}$ and the intra-sheet hydrogen bonding mat the $\mathrm{C}=\mathrm{O}$ stretching region with wave number $1660 \mathrm{~cm}^{-1}$. This inter- and intra-sheet hydrogen bonding is characteristic of chitin which gives chitin's highly insoluble property. 


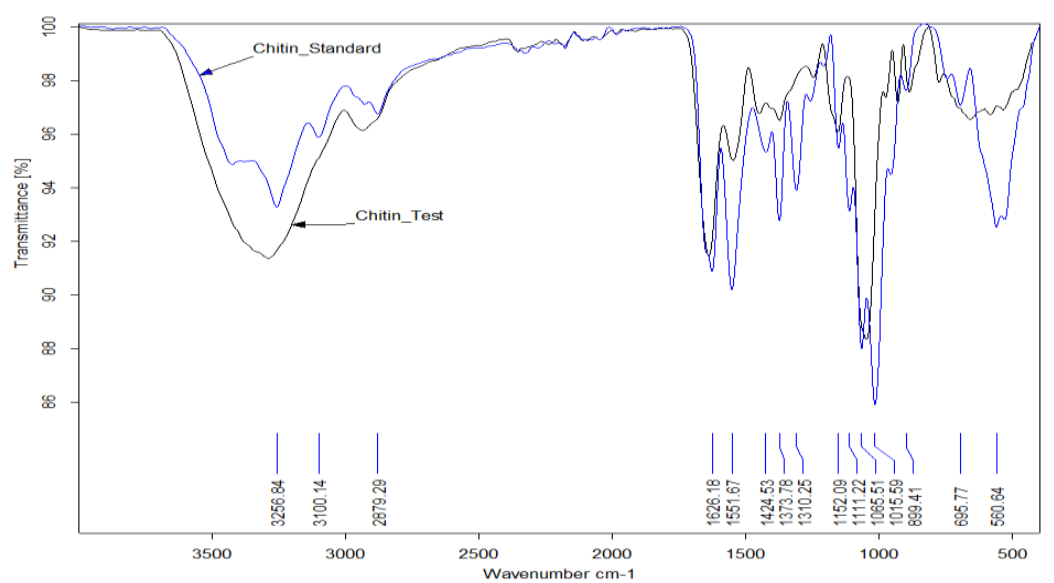

Fig. 3: FTIR of chitin extracted from M. japonicus shells compared to commercial chitin.

Table 2: Wave length of the main bands obtained by the FTIR for both commercial and extracted chitin

\begin{tabular}{cc}
\hline Frequency $\left(\mathbf{c m}^{-1}\right)$ & Assignments \\
\hline Glycopyrenose & 890 \\
Carbohyderate backbone & 1065 \\
Amide III & 1424 \\
Amide I & 1551 \\
N-acetyl ester bonds, Amide II & 1626 \\
Amino peak, alpha chitin & 3100 \\
\hline
\end{tabular}

In addition, different absorption bands within 4000-400 $\mathrm{cm}^{-1}$ range were presented in the FTIR spectra of chitosan as shown in Fig. 4 and Table 3. These bands were compared to those of standard chitosan. The absorption bands of produced chitosan were identical to those of standard chitosan. The bands ranged from 3425-2880 $\mathrm{cm}^{-1}$ related to $(\mathrm{N}-\mathrm{H})$ stretching frequency of $\mathrm{NH}_{2}$ and $(\mathrm{OH})$ groups which present in chitosan. The band at $1646 \mathrm{~cm}^{-1}$ suggests effective deacetylation band at $1650 \mathrm{~cm}^{-1}$ represent acetylated group which due to $\mathrm{C}=\mathrm{O}$.

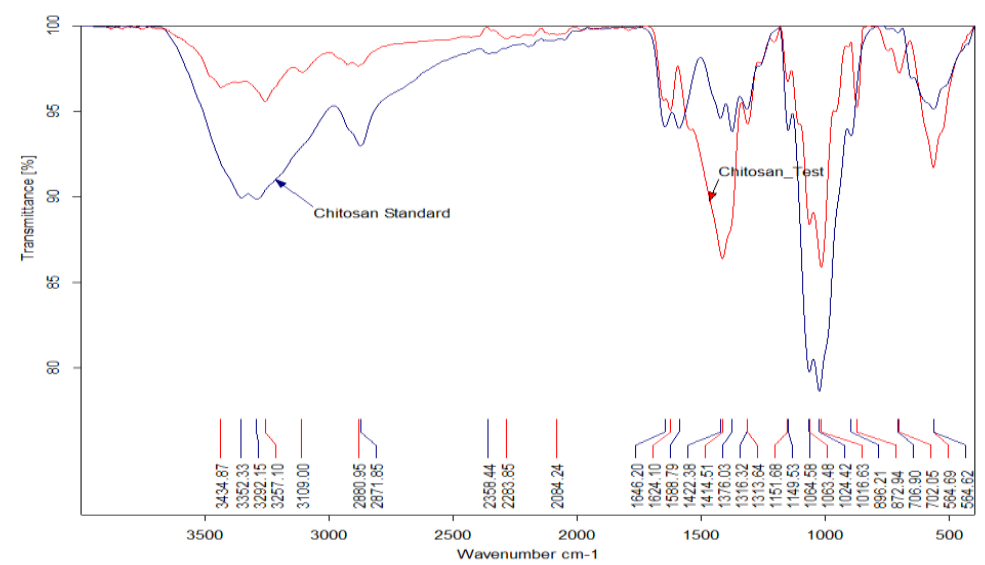

Fig. 4: FTIR of chitosan extracted from $M$. japonicus shells compared to commercial chitosan. 
Table 3: Wave length of the main bands obtained for both commercial and extracted chitosan

\begin{tabular}{ccc}
\hline Vibration modes & \multicolumn{2}{c}{ Chitosan } \\
\cline { 2 - 3 } & Standard & Produced \\
\hline NH out-of- plane blending & 706.90 & 702.05 \\
Ring stretching & 896.21 & 872.94 \\
CO stretching & 1024.42 & 1016.63 \\
$\mathrm{CH}_{2}$ bending and $\mathrm{CH}_{3}$ deformation & 1422.38 & 1414.51 \\
Amide II band & 1588.79 & ------ \\
Amide I band & 1646.20 & 1624.10 \\
CH stretching & 2871.85 & 2800.95 \\
NH stretching & 3292.15 & 3257.10 \\
\hline
\end{tabular}

In general, commercial chitosan shows bands at 3000-3500 $\mathrm{cm}^{-1}$ (NH bond) and at $1400-1650 \mathrm{~cm}^{-1}(\mathrm{C}=\mathrm{O}$ bond) (Chatterjee et al., 2005). Paul et al. (2014) revealed that the major absorption band is observed between $1220-1020 \mathrm{~cm}^{-1}$ which represents the free amino group $\left(-\mathrm{NH}_{2}\right)$ at $\mathrm{C} 2$ position of glucosamine, a major group present in chitosan. Further data obtained by Puvvada et al. (2012) revealed that their sample showed the absorption bands at the various peaks, which is similar to standard chitosan. This also shows the confirmation of chitosan (Puvvada et al., 2012).

In addition, George et al. (2011) obtained FTIR spectra of chitosan that showed a broad absorption band in the range $3000-3500 \mathrm{~cm}^{-1}$ attributed to $\mathrm{O}-\mathrm{H}$ stretching vibrations. The peaks around $2885,1650,1589,1326$ and $1080 \mathrm{~cm}^{-1}$ in the FT-IR spectrum of chitosan were due to the stretching vibrations of aliphatic $\mathrm{C}-\mathrm{H}$, Amide I (-NH deformation of $\left.-\mathrm{NHCOCH}_{3}\right)$, Amide II, Amide III and $\mathrm{C}-\mathrm{O}-\mathrm{C}$, bonds respectively. However, these are characteristics of the chitosan polysaccharide (Radhakumary et al., 2003). Similar FTIR spectrum of chitosan obtained by Mohammed et al. (2013).

The antimicrobial activities of extracted chitin and chitosan compared to corresponding commercial ones were detected. They were expressed as the diameter in millimeters of inhibition zone. Results in Fig. 5 and Table 4 showed that there was no significant difference $\mathrm{p}<0.05$ in the antimicrobial activity of the extracted compounds and commercial ones against test pathogens as the extracted compounds recorded inhibition zones ranged from 12 to $23 \mathrm{~mm}$ in diameter while the commercial compounds recorded inhibition zones of diameters ranged from 12 to 22 $\mathrm{mm}$, with Staphylococcus aureus ATCC 25923 being the most affected microbe with inhibition zone of $23 \mathrm{~mm}$ produced by extracted chitin, while the lowest zone of inhibition was recorded against Enterococcus faecalis ATCC 29212 with only 12 $\mathrm{mm}$ by commercial and extracted chitosan. Surprisingly, the inhibition zones produced by chitin either extracted or commercial recorded higher values than those by both extracted and commercial chitosan.

On the other side, both chitin and chitosan were more effective against bacteria than fungi. The degree of deacetylation has a major effect on the antimicrobial activity as it is determinant in the charge development and solubility of chitosan and increasing the degree of deacetylation will increase the free amino groups in the produced chitosan which leads to higher antimicrobial activity, as the $-\mathrm{NH}_{2},-\mathrm{OH}$ groups are considered the main reactive site in chitosan. 


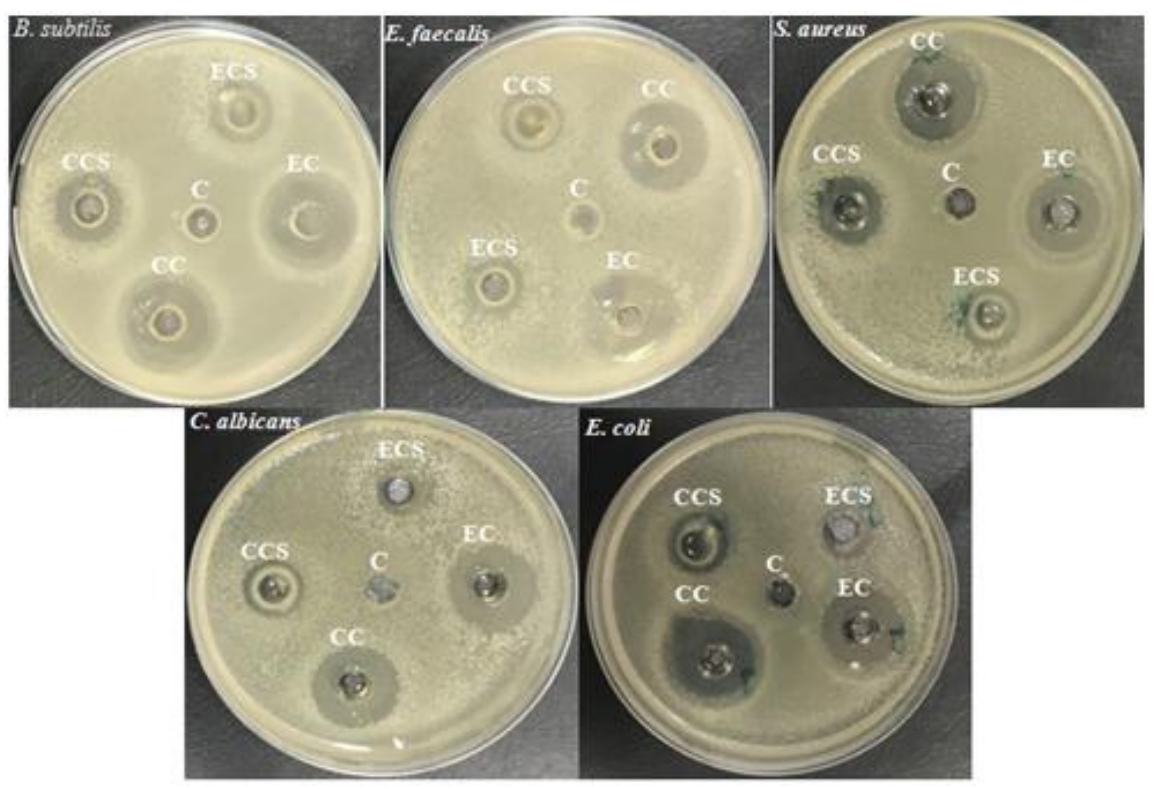

Fig. 5: Antimicrobial activity of extracted chitin and chitosan against reference strains compared to commercial chitin and chitosan (EC: Extracted Chitin, ECS: Extracted Chitosan, CC: Commercial Chitin, CCS: Commercial Chitosan).

The effectiveness of chitin and chitosan as antimicrobial agents is well documented in many studies against both bacteria and fungi. For example, Benhabiles et al. (2012) detected the antimicrobial activities of chitin and chitosan isolated from shrimp (Parapenaeus longirostris) shell waste against four Grampositive and seven Gram negative bacteria. Their data confirmed that chitin exhibited a bacteriostatic effect on Gram-negative bacteria namely, E. coli ATCC 25922, Vibrio cholerae, Shigella dysenteriae, and Bacteroides fragilis. The chitosan exhibited a bacteriostatic effect on all bacteria tested (E. coli, Pseudomonas aeruginosa, V. cholerae, S. dysenteriae, Prevotella melaninogenica, Enterobacter agglomerans, Bacillus cereus, Bacillus subtilis, Staphylococcus aureus and B. fragilis), except Salmonella typhimurium. In addition, Paul et al. (2014) analyzed chitosan derived from chitin isolated from Fenneropenaeus indicus for its physiochemical parameters, antibacterial and antifungal activity. Their data showed that the antimicrobial properties of chitosan were done at $120 \mu \mathrm{gml}^{-1}$ and showed 12 $\mathrm{mm}$ inhibition zones toward both $S$. aureus and Candida albicans. Goy et al. (2016) evaluated the effect of commercial chitosan against $S$. aureus (Gram-positive) and $E$. coli (Gram-negative) as reference bacteria. Their results, from turbidity reduction measurements, confirmed the antibacterial properties of chitosan.

On the other hand, several studies detected the bactericidal effectiveness of chitosan on Gram-positive and Gram-negative bacteria (Jeon et al., 2001; No et al., 2002; Coma et al., 2003; Dutta et al., 2009). These authors have stated that chitosan generally have stronger effects for Gram-positive bacteria (e.g. Listeria monocytogenes, B. megaterium, B. cereus, S. aureus, Lactobacillus plantarum, L. brevis, L. bulgaris, etc.) than for Gram-negative bacteria (e.g. E. coli, Pseudomonas fluorescens, Salmonella typhymurium, V. parahaemolyticus, etc.). The effectiveness of chitosan on gram-positive or gram-negative bacteria is however, somewhat controversial. One of the suggested hypothesis for this effect is declared by Raafet et al. (2008) who stated that, this difference in sensitivity is largely ascribed to the different structure of Gram positive and Gram negative bacteria cell envelopes, as a possible mechanism of action for chitosan antimicrobial activity is due to binding to 
teichoic acids present in the cell wall of Gram positive bacteria, coupled with membrane lipids extraction which trigger a series of event that result in bacterial cell death eventually.

As bacteria, the chitosan activity against fungus is assumed to be fungistatic rather than fungicidal (Assis, 2008). Generally, chitosan has been reported as being very effective in inhibiting spore germination, germ tube elongation and radial growth (El Ghaouth et al., 1992). Inhibition rate against plant fungus such as Phomopsis asparagi, Cucumernum owen, Rhizoctonia solani and Fusarium oxysporum have been known to occur with low chitosan concentration (20-150 $\mathrm{mgl}^{-}$ $\left.{ }^{1}\right)$ (Zhang et al., 2003). However, most of the studies have been done on yeasts and moulds associated with food spoilage and plant diseases.

Table 4: Antimicrobial activity ( $\mathrm{mm}$ ) of extracted chitin and chitosan compared to commercial chitin and chitosan, values are mean of three independent experiments.

\begin{tabular}{lcccc}
\hline \multirow{2}{*}{ Microbe } & \multicolumn{2}{c}{ Chitin } & \multicolumn{2}{c}{ Chitosan } \\
\cline { 2 - 5 } & Extracted & Commercial & Extracted & Commercial \\
\hline E. coli ATCC 8739 & 20 & 20 & 14 & 13 \\
E. faecalis ATCC 29212 & 21 & 20 & 12 & 12 \\
S. aureus ATCC 25923 & 23 & 22 & 16 & 15 \\
B. subtilis ATCC 6633 & 22 & 22 & 16 & 16 \\
C. albicans ATCC 10231 & 22 & 22 & 15 & 15 \\
\hline
\end{tabular}

Indeed, discrepancies in the obtained results is recorded in many studies. This variation is expected to be due to both intrinsic and extrinsic factors. For instance, degree of deacetylation, viscosity, concentration, test microorganism, $\mathrm{pH}$ and temperature are all associated with the chitosan activity under in vitro conditions (Raafat and Sahl, 2009). For example, Malinowska-Pañczyk et al. (2015) estimated the antimicrobial properties of chitosan solutions and films against selected bacteria and the effect of chitosan incorporation into gelatin films. They found that the bactericidal effect of chitosan solutions increased with time and temperature of sample incubation. The degree of deacetylation has a major effect in the antimicrobial activity as it is determinant in the charge development and solubility of chitosan and increasing the degree of deacetylation will increase the free amino groups in the produced chitosan which leads to higher antimicrobial activity, as the $\mathrm{NH}_{2},-\mathrm{OH}$ groups are considered the main reactive site in chitosan.

\section{CONCLUSION}

In this study, we extracted and characterized chitin and chitosan from $M$. japonicus shell. The current study supports the following points:

1- Shrimp shell waste (M. japonicus) can be used as a promising substrate for the chitin production using standard methods.

2- Deacetylation is an effective process to produce chitosan from the extracted chitin.

3- The chitin and chitosan exhibited considerable antimicrobial activities against pathogenic microorganisms compared to commercial chitin and chitosan.

\section{ACKNOWLEDGEMENT}

Authors would like to thank Prof. Dr. Amany M. El-Sikily; Professor of Biochemistry, Pollution Lab, NIOF, for her help in completing the FTIR analysis. 


\section{REFERENCES}

Abdou, E.S.; Nagy, K.S.A. and Elsabee, M.Z. (2007). Extraction and characterization of chitin and chitosan from local sources. Bioresource Technol., 99: 1359-1367.

Acharya, B.; Kumar, V.; Varadaraj, M.C.; Lalitha, R. and Rudrapatnam, N. (2005). Characterization of chito-oligosaccharides prepared by chitosanolysis with the aid of papain and pronase, and their bactericidal action against Bacillus cereus and E. coli. Biochem. J., 391: 167-175.

Andres, Y.; Giraud, L.; Gerente, C. and Le Cloirec, P. (2007). Antibacterial effects of chitosan powder: mechanisms of action. Environ. Technol., 28: 1357-1363.

Assis, O.B.G. (2008). Avaliação, por análise de imagens,da ação fungistática de coberturas de quitosana em maçãs minimamente processadas. Monografia de Especialização, Universidade Federal de Lavras, Brasil.

Benhabiles, M.S.; Salah, R.; Lounici, H.; Drouichhe, N.; Goosen, M.F.A. and Mameri, N. (2012). Antibacterial activity of chitin, chitosan and its oligomers prepared from shrimp shell waste. Food Hydrocoll., 29: 48-56.

Chatterjee, S.; Adhya, M.; Guha, A.K. and Chatterjee, B.P. (2005). Chitosan from Mucor rouxii: production and physico-chemical characterization. Process Biochem., 40: 395-400.

Chen, C.S.; Liau, W.Y. and Tsai, G.J.J. (1998). Antibacterial effects of Nsulfonated and $\mathrm{N}$-sulfobenzoyl chitosan and application to oyster preservation. Food Prot., 61(9): 1124-1128.

Chistiakov, D.A.; Hellemans, B. and Volckaert, F.A.M. (2007). Review on the immunology of European sea bass Dicentrarchus labrax. Vet. Immunol. Immunopathol., 117: 1-16.

Coma, V.; Martial-Gros, A.; Garreau, S.; Copinet, A.; Salin, F. and Deschamps, A.J. (2002). Biodegradable colour polymeric film (starch-chitosan) development: characterization for packaging materials. Food Sci., 67: 11621169.

Coma, V.; Deschamps, A. and Martial-Gros, A.J. (2003). Bioactive packaging materials from edible chitosan polymer-antimicrobial activity assessment on dairy-related contaminants. Food Sci., 68(9): 2788-2792.

Dutta, P.K.; Tripath, S.; Mehrotra, G.K. and Dutta, J. (2009). Perspectives for chitosan based antimicrobial films in food applications. Food Chem., 114: 1173-1182.

EI, Badawy, M.E.; Stevens C.V.; Smagghe G. and Steurbaut W. (2003). Review Chitosan as antimicrobial agent: applications and mode of action. Biomacromol., 4(6): 1457-65.

El Ghaouth, A.; Arul, J.; Grenier, J. and Asselin, A. (1992). Antifungal activity of chitosan on post-harvest pathogens: induction of morphological and cytological alterations in Rhizopus stolonifer. Phytopathol., 82: 398-402.

Fouad, D.R.G. (2008). Chitosan as an antimicrobial compound Modes of action and resistance mechanisms. PhD thesis, 195 pp, University of Bonn, Germany.

George, S.; Samy, K.; Guru, S.; Vasanthi, N.S. and Kannan. K.P. (2011). Extraction, purification and characterization of chitosan from endophytic fungi isolated from medicinal plants. World J. Sci. Tech., 1(4): 43-48.

Gildberg, A. and Stenberg, E. (2001). A new process for advanced utilization of shrimp waste. Process Biochem., 36: 809-812. 
Goy, R.C.; de Britto, D. and Assis, O.B.G. (2009). A review of the antimicrobial activity of chitosan. Polímeros. Ciência e Tecnologia., 19(3): 241-247.

Goy, R.C.; Moraisb, S.T.B. and Assis, O.B.G. (2016). Evaluation of the antimicrobial activity of chitosan and its quaternized derivative on E. coli and S. aureus growth Revista Brasileira de Farmacognosia., 26: 122127.

Ibrahim, H.A.H.; Hussein A.E.R. and Abd El-Waness M.S. (2015). Bioethanol production from shrimp shell waste using marine Alcaligenes feacalis MS7 and Candida albicans ATCC 14053. Blue Biotechnol. J., 3(3): 156 -160.

Islam M.; Masum, S. and Mahbub, K.R. (2011). In vitro antibacterial activity of shrimp chitosan against Salmonella paratyphi and Staphylococcus aureus. J. Bangladesh Chem. Soc., 24(2): 185-190.

Jeon, Y.J.; Park, P.J. and Kim, S.K. (2001). Antimicrobial effect of chitoologosaccharides produced by bioreactor. Carbohyd. Polym., 44: 71-76.

Kean, T. and Thanou, M. (2011). Chitin and chitosan: sources, production and medical applications. In "Renewable resources for functional polymers and biomaterials". Williams P.A. (Ed.). RSC Publishing, pp. 292-318.

Kong, M.; Chen, X.G.; Xing, K. and Park H.J. (2010). Antimicrobial properties of chitosan and mode of action: a state of the art review. Int. J. Food Microbiol., 144(1): 51-63.

Kumirska, J.; Czerwicka, M.; Kaczynski, Z.; Bychowska, A.; Brzozowski, K.; Thöming, J. et al. (2010). Application of spectroscopic methods for structural analysis of chitin and chitosan. Mar. Drugs., 8: 1567-1636.

Liu, H.; Du, Y.; Wang, X. and Sun, L. (2004). Chitosan kills bacteria through cell membrane damage. Int. J. Food Microbiol., 95(2): 147-55.

Malinowska-Pañczyk, E.; Wojtasz-Pajk, A.; Staroszczyk, H.; Gottfried, K. and Koodziejska, I. (2015). Antimicrobial properties of chitosan solutions, chitosan films and gelatin-chitosan films. Polimery., 60: nr 11-12.

Márcia de Pádua, M.; Fontoura, P.S.G. and Mathias, A.L. (2004). Chemical composition of Ulvaria oxysperma (Kützing) Bliding, Ulva lactuca (Linnaeus) and Ulva fasciata (Delile). Braz. Arch. Biol.Techno., 1: 49-55.

Mohammed, M.H.; Williams, P.A. and Tverezovskaya, O. (2013). Extraction of chitin from prawn shells and conversion to low molecular mass chitosan. Food Hydrocolloid., 31: 166-171.

Muzzarelli, R.A. and Rochetti, R. (1985). Determination of the degree of deacetylation of chitosan by first derivative ultraviolet spectrophotometry. J. Carbohydr. Polym., 5: 461-472.

No, H.K.; Park, N.Y.; Lee, S.H. and Meyers, S.P. (2002). Antibacterial activity of chitosans and chitosan oligomers with different molecular weights. Int. J. Food Microbiol.74: 65-72.

Paul, N.; Jayan, A.; Sasikumar, C.S. and Cherian, S.M. (2014). Extraction and purification of chitosan from chitin isolated from sea prawn Fenneropenaeus indicus. Asian J. Pharm. Clin. Res., 7(4): 201-204.

Puvvada, Y.S., Vankayalapati, S. and Sukhavasi, S. (2012). Extraction of chitin from chitosan from exoskeleton of shrimp for application in the pharmaceutical industry. Int. Curr. Pharm. J. 1(9): 258-263.

Qi, L., Xu, Z., Jiang, X., Hu, C. and Zou, X. (2004). Preparation and antibacterial activity of chitosan nanoparticles. Carbohydr. Res. 339(16): 2693-700.

Raafat, D.; Bargen, K.; Haas, A. and Sahl, H.G. (2008). Insights into the mode of action of chitosan as an antibacterial compound. Appl. Environ. Biol.; 74: 3764-3773. 
Raafat, D. and Sahl, H.G. (2009). Chitosan and its antimicrobial potential - a critical literature survey. Microb. Biotechnol., 2: 186-201.

Radhakumary, C.; Divya, G.; Nair, P.D.; Mathew, S. and Nair, C.P.R. (2003). Graft copolymerization of 2-Hydroxy ethyl methacrylate onto chitosan with Cerium (IV) Ion I. synthesis and characterization. J. Macromol. Sci. Part APure and App. Chem., 40: 715-730.

Rayn, M.P.; Rea, M.C.; Hill, C. and Ross, R.P. (1996). An application in cheddar cheese manufacture for a strain of Lactococcus lactis producing a novel broadspectrum bacteriocin, lacticin 3147. Appl. Environ. Microbiol., 62: 612-619.

Rinaudo, M. (2006). Chitin and chitosan: properties and applications. Prog. Polym. Sci., 31: 603-632.

Rodde, R.H.; Einbu, A. and Vårum, K.M. (2008). A seasonal study of the chemical composition and chitin quality of shrimp shells obtained from northern shrimp (Pandalus borealis). Carbohyd. Polym., 71: 388-393.

Shahidi, F.; Arachchi, J. and Jeon, Y.J. (1999). Comparison of dye adsorption of three forms of chitosan. Trends. Food Sci. Technol., 10: 37-51.

Toan, N.V.; Hanh, T.T. and Thien, P.V.M. (2013). Antibacterial activity of chitosan on some common food contaminating microbes. Open Biomater. J., 4: $1-5$.

Torrecillas, S.; Makol, A.; Caballero, M.J.; Montero, D.; Robaina, L.; Real, F., et al. (2007). Immune stimulation and improved infection resistance in European sea bass (Dicentrarchus labrax) fed mannan oligosaccharides. Fish Shellfish Immun., 23: 969-981.

Yokoyama, M.Y. and Guimarães, O. (1975). Determinação dos teores de Na, K, O e proteínas em algas marinhas. Acta Biológica Paranaense, 4: 19-24.

Zhang, M.; Tan, T.; Yuan, H. and Rui, C.J. (2003). Insecticidal and fungicidal activities of chitosan and oligo-chitosan. Bioact. Compatible Polym., 18: 391400 .

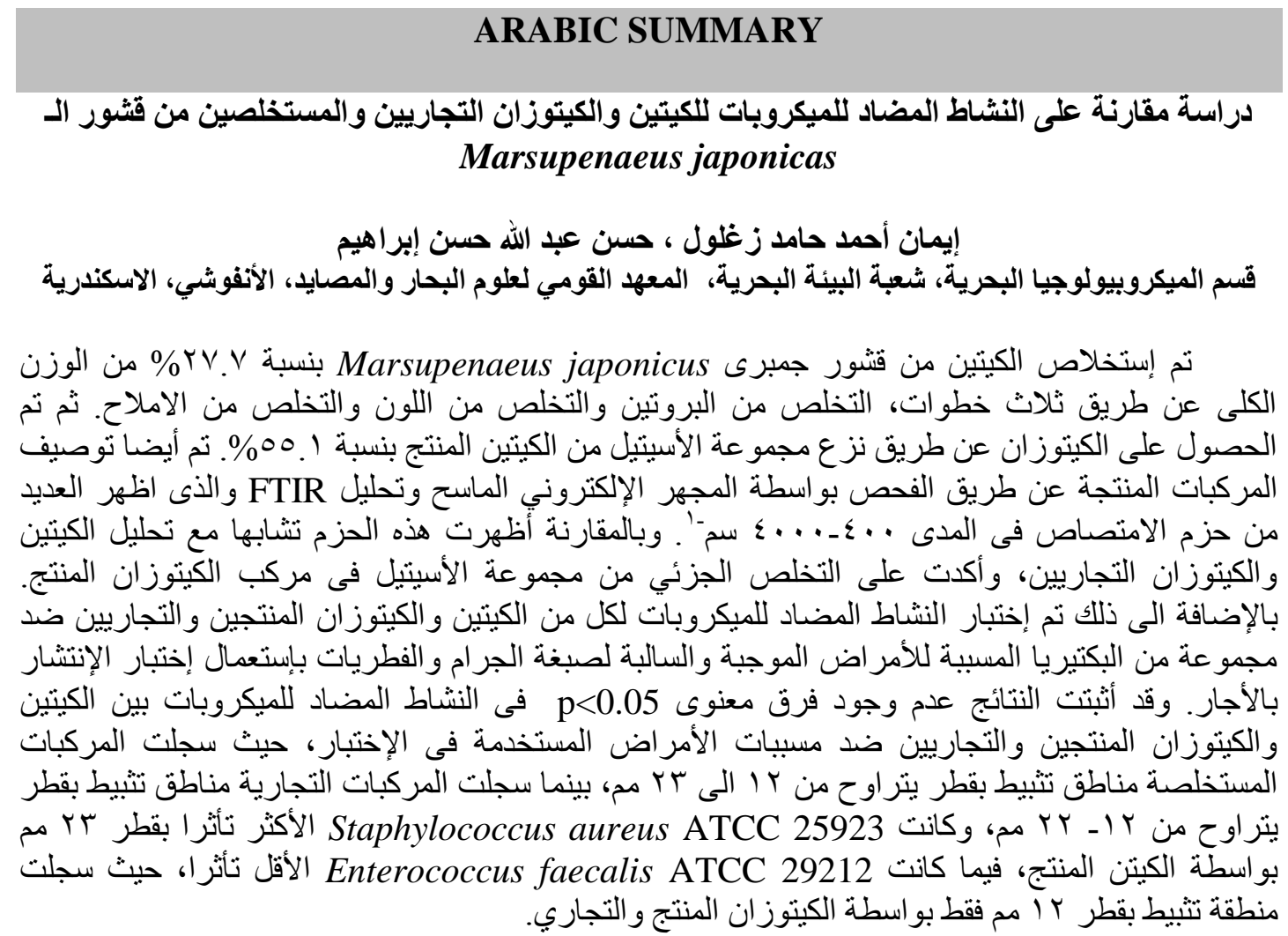

